\title{
TRANSFORMASI PRINSIP MATEMATIKA PADA PERMAINAN TRADISIONAL ANAK MADURA MENJADI MASALAH KONTEKSTUAL DALAM PEMBELAJARAN MATEMATIKA DI SD
}

\author{
Umi Hanik \\ Prodi Pendidikan Guru Sekolah Dasar Fakultas Ilmu Pendidikan Universitas Trunojoyo Madura \\ umy_tenmat@yahoo.com
}

\begin{abstract}
Abstrak
Madura merupakan salah satu etnis di Provinsi Jawa Timur yang memiliki budaya, perilaku dan cara hidup yang khas. Salah satunya adalah permainan tradisional yang berkembang di kalangan anak-anak. Sedangkan matematika diciptakan di tengah-tengah budaya. Kondisi tersebut dapat dimanfaatkan dalam pembelajaran dengan mentransformasi prinsip-prinsip matematika yang ada dalam setiap permainan menjadi masalah yang kontekstual dalam pembelajaran matematika di sekolah dasar. Artikel ini merupakan implementasi dari penelitian yang berjudul Etnomatematika Permainan Tradisional Anak Madura dan diharapkan dapat membantu praktisi pendidikan khususnya di tingkat sekolah dasar dalam membuat permasalahan matematika kontekstual yang serupa. Artikel memuat contoh masalah matematika yang kontekstual dengan mengambil prinsip dan aktivitas matematika yang ada pada permainan tradisional anak Madura.
\end{abstract}

Kata Kunci: Prinsip matematika, contoh masalah matematika kontekstual, permainan tradisional anak Madura.

\section{PENDAHULUAN}

Gadget merupakan salah satu produk dari berkembangnya teknologi informasi. Sebagian orang tua telah mengenalkan gadget pada anak-anak mereka untuk berbagai keperluan sesuai usia, balita sekalipun. Selain gadget, televisi juga merupakan salah satu media yang dikenalkan orang tua pada anaknya melalui tayangantayangannya sehingga anak-anak betah untuk berlamalama di depan televisi. Dampaknya adalah anak-anak jarang melakukan kegiatan olah fisik. Salah satu kegiatan olah fisik yang biasanya dilakukan anak-anak adalah bermain, salah satunya permainan tradisional seperti tanjan, lajengan dan sebagainya. Sehingga berkembangnya produk-produk teknologi informasi tersebut merupakan salah satu penyebab punahnya permainan tradisional.

Namun dibalik kondisi tersebut, Madura merupakan salah satu tempat di Indonesia yang masih bisa kita dapati sejumlah permainan tradisional yang dimainkan oleh anak-anak usia sekolah dasar. Hal ini bisa dimanfaatkan dalam pembelajaran dengan membuat masalah yang kontekstual.

Permainan tradisional merupakan hasil pemikiran, kreatifitas, prakarsa coba-coba dan olah budi para pendahulu kita (Surahmi, 2016: 132). Sehingga dalam permainan tradisional ada nilai-nilai yang menuntun dan mengarahkan mereka pada pembelajaran berupa kegiatan sosial, kebersamaan maupun pengetahuan terkait pelajaran misalnya matematika.
Fakta pengetahuan matematika yang diperoleh diluar pembelajaran matematika secara formal yang mengakibatkan munculnya kajian baru dalam pendidikan matematika dinamakan ethnomathematics (etnomatematika). Etnomatematika ini dipelopori oleh Ubiratan D'Ambrosio tahun 1985. Dia mengungkapkan bahwa etnomatematika merupakan jembatan antara antropolog dengan ahli sejarah dan matematika, hal tersebut merupakan sebuah langkah penting untuk mengakui matematika dari bentuk yang berbeda.

Definisi etnomatematika sebagai kajian ilmu diambil dari definisi yang dikemukakan oleh Barton (1996: 196) dalam tesisnya bahwa etnomatika diartikan sebagai suatu kajian pengetahuan yang dilakukan untuk meneliti cara sekelompok orang pada kebudayaan tertentu dalam memahami, mengekspresikan, dan menggunakan konsep-konsep serta praktik dalam kebudayaan yang dideskripsikan oleh peneliti sebagai sesuatu yang matematis.

Kaitannya dengan matematika, beberapa permainan tradisional mengandung prinsip-prinsip matematika. Misalnya dalam permainan tanjen seribu, anak secara tidak langsung belajar tentang pecahan nilai mata uang dan operasi hitung. Dalam permainan dhák koh, anak belajar pembagian, perkalian, penjumlahan, pengurangan, berhitung dan pengaturan strategi dan kecermatan untuk bisa menang dalam permainan. Prinsip-prinsip matematika tersebut muncul dari aktivitas-aktivitas yang 
dilakukan selama permainan berlangsung. Diantara aktivitas-aktivitas tersebut ada bersifat matematis sehingga dikenal dengan aktivitas matematis.

Prinsip-prinsip matematika yang ada dalam permainan tradisional dapat membantu guru khususnya guru sekolah dasar untuk membuat masalah matematika yang kontekstual. Nelissen (tanpa tahun) mendefinisikan konteks sebagai situasi yang menarik perhatian anak, dan yang mereka dapat kenali dengan baik. Soedjadi (2007) menjelaskan kontekstual sebagai lingkungan siswa yang nyata baik aspek budaya maupun geografis. Di dalam matematika hal tersebut tidak selalu diartikan "konkret" tetapi dapat juga yang telah dipahami siswa atau dapat dibayangkan. Sehingga masalah matematika yang kontekstual adalah masalah matematika yang berkaitan dengan konteks sebagaimana telah didefinisikan.

Tulisan ini mencoba untuk mentransformasi prinsip-prinsip matematika yang ada dalam beberapa permainan tradisional anak Madura menjadi masalah matematika yang kontekstual. Tidak semua permainan tradisional anak akan dibahas disini, melainkan terbatas pada permainan tanjen seribu, lajengan, dan $d h$ koh.

\section{METODE}

Artikel ini memberikan contoh-contoh praktis masalah kontekstual dari permainan tradisional anak Madura dengan mengambil prinsip matematika yang ada dan aktivitas matematika yang dilakukan pada setiap permainan.

Contoh masalah juga disertai penggunaan dalam pembelajaran apakah disajikan di awal, tengah ataupun akhir pembelajaran. Selain itu juga disertai penyesuaian dengan Standar Isi 2006.

\section{HASIL DAN PEMBAHASAN Kontekstual dan Macamnya}

De Lange (dalam Zulkardi, 2006) menjelaskan ada empat masalah konteks atau situasi sebagai berikut.

Pertama, personal siswa - situasi yang berkaitan dengan kehidupan sehari-hari siswa baik dengan keluarga, teman sepermainan, teman sekelas dan kesenangannya. Berikut adalah contoh soal terkait dengan personal siswa.

$A$ dan B teman sebangku. Jarak rumah A ke sekolah $3 \mathrm{~km}$ dan jarak rumah B ke sekolah 5 km. Berapakah jarak rumah mereka?

Kedua, sekolah/akademik - situasi yang berkaitan dengan kehidupan akademik di sekolah, ruang kelas, dan kegiatan-kegiatan yang terkait dengan proses pembelajaran. Berikut adalah contoh soal terkait dengan sekolah /akademik.
Jika siswa perempuan berjumlah 17 orang berbaris secara simetri dengan siswa laki-laki, maka berapakah jumlah seluruh siswa?

Ketiga, masyarakat/publik - situasi yang terkait dengan kehidupan dan aktivitas masyarakat sekitar dimana siswa tersebut tinggal. Contohnya sebagai berikut.

Semangka yang dijual di pasar berbentuk kubus. Setelah diukur, panjangnya $30 \mathrm{~cm}$, lebarnya 25 $\mathrm{cm}$, dan tingginya $20 \mathrm{~cm}$. Penjual membelah sedikit semangkanya sehingga diketahui ketebalan kulitnya $2 \mathrm{~cm}$. Berapakah volume semangka bagian dalam? Berapakah berat semangka?

Gambar 1. Semangka berbentuk kubus

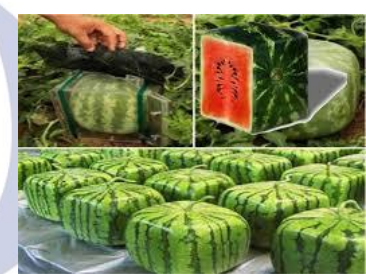

Sumber: https://www.google.co.id

Keempat, saintifik/matematik - situasi yang berkaitan dengan fenomena dan substansi secara saintifik atau matematika itu sendiri. Contohnya sebagai berikut.

Bagaimanakah luas bangun dibawah?

Gambar 2. Bangun datar dengan luas sama tapi bentuk berbeda

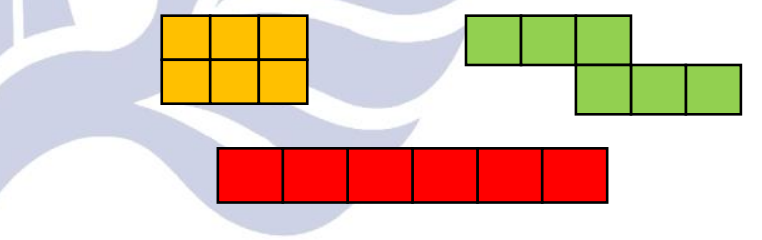

Masalah kontekstual dapat disajikan di awal, tengah maupun akhir pembelajaran. Jika disajikan di awal pembelajaran, untuk memungkinkan siswa membangun/menemukan suatu konsep, definisi, operasi ataupun sifat matematika serta cara pemecahan masalah tersebut. Jika disajikan di tengah pembelajaran, dimaksudkan untuk memantapkan apa yang telah dibangun/ditemukan. Jika di akhir pembelajaran, dimaksudkan untuk untuk mampu mengaplikasikan apa yang telah dibangun/ditemukan (Soedjadi, 2007).

\section{Aktivitas Matematika}

Bishop (1997: 1-2) menjelaskan tentang aktivitasaktivitas matematis, yakni (1) counting (membilang), (2) locating (melokasikan), (3) measuring (mengukur/menakar), (4) designing (mendesain), (5) playing (bermain), dan (6) explaining (menjelaskan).

Counting (membilang), terkait dengan pertanyaan "how many". Alat yang digunakan sebagai counter 
(penghitung) diantaranya bagian tubuh (misal jemari), batu, dan tongkat. Salah seorang peneliti menganalisa lebih dari 2000 cara membilang yang berbeda yang ditemukan di Papua Nugini dan Oceania.

Locating (melokasikan), aktivitasnya antara lain menemukan jalan, navigasi (dalam berlayar), mengorientasikan diri, dan menggambarkan keadaan (hubungan) dengan benda lain. Orang di dunia menggunakan arah kompas, bintang, matahari, angin, dan peta sebagai petunjuk jalan dan posisi/keberadaan mereka.

Measuring (mengukur/menakar), terkait dengan pertanyaan "how much". Bentuk pertanyaan ini dapat ditanyakan dan dijawab dimanapun. Apakah menanyakan kuantitas (banyak) bahan, makanan, atau uang sebagai barang yang bernilai.

Designing (mendesain), terkait dengan merancang obyek untuk disajikan dalam tujuan yang berbeda. Playing (bermain), terkait dengan perkembangan dalam berpikir matematis seperti dalam permainan teka-teki, aturan permainan, strategi untuk menang, menebak, dan kesempatan. Hal itu menunjukkan bagaimana bermain memberikan kontribusi terhadap perkembangan dalam berpikir matematis.

Explaining (menjelaskan), terkait dengan pertanyaan "why" misalnya mengapa bentuk geometri saling berkaitan, mengapa pola bilangan dapat terjadi. Matematikawan sering kali sering tertarik untuk menjawab pertanyaan tersebut.

Dari aktivitas matematis ini muncul prinsip-prinsip matematika. Prinsip matematika adalah objek matematika yang kompleks. Prinsip dapat terdiri atas beberapa fakta, beberapa konsep yang dikaitkan oleh suatu relasi ataupun operasi. Secara sederhana dapatlah dikatakan bahwa prinsip adalah hubungan antara berbagai objek dasar matematika. Prinsip dapat berupa aksioma, teorema, sifat dan sebagainya (Soedjadi, 2000).

\section{Permainan Tradisional Anak Madura dan} Transformasi Prinsip Matematikanya menjadi Masalah Matematika yang Kontekstual

Dari penelitian Umi Hanik tentang Etnomatematika Permainan Anak Madura, terdapat berbagai macam permainan tradisional anak yang berkembang di Madura yang mengandung prinsip-prinsip matematika. Tidak semua permainan akan dibahas disini, hanya sebagian saja yakni permainan tanjan seribu, lajengan, dan dhåkkoh.

\section{Permainan tanjen (engkling/engklek) seribu}

Tanjen seribu merupakan salah satu pola dari permainan tanjen yang mendunia yang bisa dimainkan lebih dari dua orang. Nilai-nilai pecahan mata uang yang ada pada permainan ini adalah $\mathrm{Rp} 1.000,00$, Rp 500,00, Rp 100,00, Rp 50,00, dan Rp 25,00. Namun sekarang diubah menjadi Rp 10.000,00, Rp 5.000,00, Rp 2000,00, $1.000,00$, dan Rp 500,00 atau bisa jadi ada pola yang lain.

Aturan mainnya yakni (a) setiap pemain harus memiliki tambhuan (ganco/gacok), biasanya berasal dari pecahan genteng, (b) fase tanjennya meliputi tambhuan yang dilempar ke kotak 1 hingga kotak 6 (lihat gambar 1), tambhuan yang ditaruh di tangan (punggung telapak tangan, lipatan siku tangan), tambhuan yang ditaruh di kepala, tambhuan yang ditaruh di kaki, tak tok (berjalan melalui kotak tanpa melihat dengan tambhuan ditaruh di punggung telapak tangan), (c) pergantian pemain terjadi jika salah satu dari kondisi ini terjadi, yakni pemain gagal memasukkan tambhuan ke kotak uang dengan tepat, lemparan tambhuan tidak masuk di kotak pada setiap fase atau tambhuan terjatuh dari tangan, kepala atau kaki sebelum masuk kotak uang, dan (d) pemain yang dinyatakan menang apabila memperoleh skor tertinggi dan jika seri dipilih yang telah melalui fase minimal.

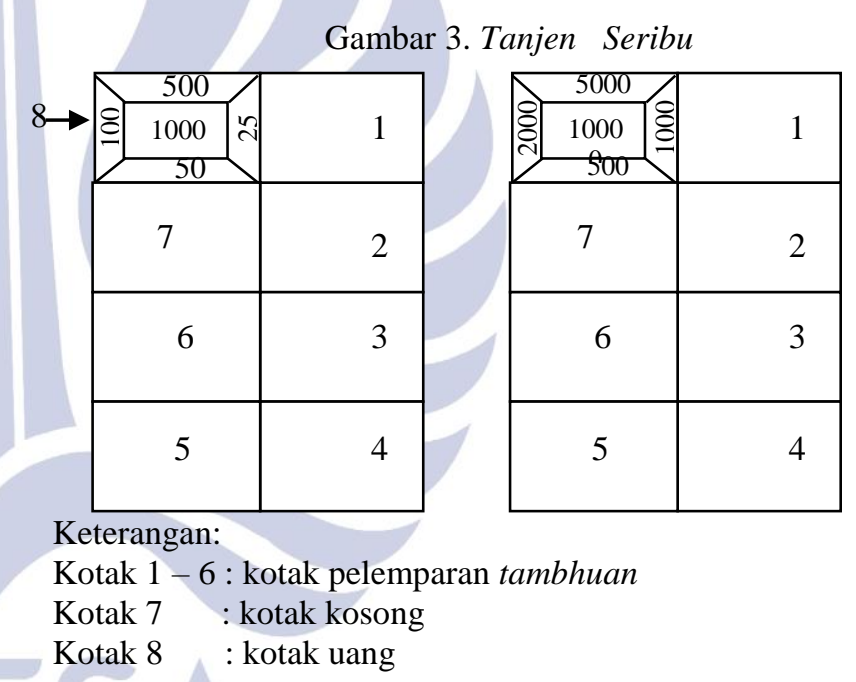

Aktivitas matematika yang dilakukan dalam permainan ini yakni measuring (mengukur atau menakar) dan playing (bermain). Playing dalam permainan tanjen seribu ada pada aturan permainannya. Hal yang perlu digaris bawahi disini adalah tidak semua permainan penting dari sudut pandang matematika tetapi teka-teki, aturan permainan, strategi untuk menang, menebak, dan kesempatan membantu mengembangkan pola pikir matematis.

Prinsip matematika yang bisa diambil dari permainan ini adalah macam-macam pecahan nilai mata uang uang dan operasi hitung. Sesuai dengan Standar Isi 2006, permainan ini bisa dibawa dalam pembelajaran dengan mentransformasi prinsip yang ada menjadi masalah kontekstual di kelas III semester 1 dan kelas IV semester 1, yaitu pada standar kompetensi memahami dan menggunakan sifat-sifat operasi hitung bilangan dalam pemecahan masalah dengan salah satu kompetensi 
dasarnya adalah memecahkan masalah perhitungan termasuk yang berkaitan dengan uang.

Contoh masalah matematika yang kontekstual dari permainan tanjen seribu sebagai berikut.

a. Perhatikan kotak uang pada permainan tanjen seribu di bawah. Isilah sesuai dengan yang apa telah kamu ketahui pada permainan tanjen seribu!

Gambar 4. Kotak Uang

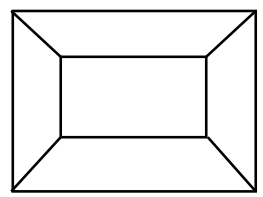

Masalah kontekstual diatas dimaksudkan untuk mengingatkan kembali atau mengenalkan nilai-nilai pecahan mata uang. Dari masalah tersebut, dimungkinkan jawaban dari setiap siswa akan berbeda. Selanjutnya siswa dapat mengingat kembali nilai pecahan mata uang bahkan mengenal nilai pecahan uang yang sebelumnya tidak diketahui. Disini siswa telah membangun pengetahuan tentang nilai-nilai pecahan mata uang.

b. Perhatikan kotak uang pada permainan tanjen seribu di bawah. Isilah dengan pecahan nilai mata uang yang lain diluar permainan tanjen seribu! Diskusikan dengan teman sebangku!

Gambar 5. Kotak Uang

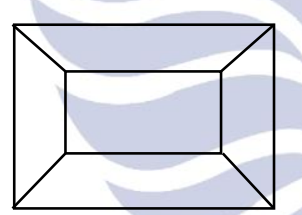

Masalah kontekstual diatas dimaksudkan untuk memantapkan pengetahuan siswa tentang pecahan nilai mata uang. Siswa akan lebih banyak mengetahui pecahan nilai mata uang selain yang ada melalui permainan tanjen seribu.

c. Pada permainan tanjen seribu, gancu Ani masuk dalam kotak uang dengan nominal Rp 5000,00 sehingga Ani mendapat kesempatan bermain pada fase berikutnya. Pada fase kotak kedua, gancunya berhasil lagi masuk kotak uang dengan nominal $R p$ 2.000,00. Berarti Ani sekali lagi mendapat kesempatan bermain lagi. Namun pada kesempatan tersebut, gancu Ani berada di kotak uang pada posisi di tengah-tengah antara nominal Rp 2000,00 dan Rp 5000,00. Berapa skor uang yang telah Ani kumpulkan?

Penyelesaian masalah diatas menggunakan operasi hitung bilangan yang telah dipelajari siswa pada kompetensi dasar sebelumnya. Disini siswa mencoba mengaplikasikan penggunaan sifat-sifat operasi hitung pada masalah yang berkaitan dengan uang.

d. Ani dan Ina bermain tanjen seribu. Di tengahtengah permainan, Ani dipanggil Ibunya sehingga permainan harus berakhir. Ani mendapat skor uang Rp 32.000,00 begitu juga Ina. Dengan skor tersebut Ani berada pada fase gancu di kotak kelima sedangkan Ina pada fase gancu di atas punggung telapak tangan. Siapakah yang menang?

Masalah kontekstual ini dapat digunakan sebagai pengayaan di kelas III dan IV semester 1. Masalah diatas mengandung aturan permainan tanjen seribu sehingga memberikan kontribusi terhadap perkembangan dalam berpikir matematis siswa.

\section{Lajengan}

Lajengan merupakan permainan tradisional Madura yang biasa dimainkan anak laki-laki. Permainan ini bisa dikompetisikan bisa juga tidak. Jika ada kompetisi kekuatan tali lajengan maka benang/ tali lajengan akan digelas menggunakan pecahan kaca yang dimasak dengan air terlebih dahulu kemudian dioleskan pada tali dan dijemur hingga kering. Tujuannya adalah agar benangnya menjadi tajam sehingga mampu memutus benang lawan.

Lajengan dibuat dari bahan tipis berkerangka yang diterbangkan ke udara dan terhubungkan dengan benang ke daratan oleh pengendalinya. Permainan ini menggunakan kekuatan angin sebagai pengangkatnya. Untuk mengangkatnya ke atas atau menerbangkannya memerlukan bantuan orang lain.

Lajengan merupakan wujud dari bangun datar layang-layang sehingga prinsip matematika yang ada pada lajengan adalah terkait dengan layang-layang yakni konsep bangun datar layang-layang, sifat dan konsep luas layang-layang. Aktivitas matematika yang dilakukan dalam permainan ini adalah locating (melokasikan), designing (mendesain) dan playing (bermain). Seseorang yang bermain lajengan perlu mencari lokasi strategis untuk menerbangkannya berdasarkan arah hembusan angin. Seseorang dapat mendesain dan membuat sendiri lajengan dengan ukuran sesuai yang dikehendaki dengan konsep simetris maupun non simetris. Ketika lajengan dikompetisikan, pemain berpikir bagaimana strategi mengarahkan lajengan untuk bisa menang berdasarkan kriteria yang telah ditetapkan apakah berdasarkan ketinggian, keindahan, kekuatan tali, kreatifitas dan lainlain.

Sesuai dengan Standar Isi 2006, permainan ini bisa dibawa dalam pembelajaran dengan mentransformasi prinsip yang ada menjadi masalah kontekstual di (1) kelas I semester 2, (2) kelas II semester 2, (3) kelas III semester 2, (4) kelas IV semester 1, dan (5) kelas V semester 2 . 
Contoh masalah matematika yang kontekstual dari permainan lajengan disini dipilih untuk kelas $\mathrm{V}$ semester 2 sebagai berikut.

a.

Gambar 6. Lajengan (Layangan)

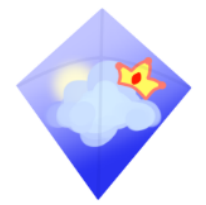

Sumber: https://layangan.deviantar.com

Buatlah sebuah lajengan (bentuk layang-layang) dari bahan yang sudah disediakan (kertas, bambu, benang, lem) secara berkelompok. Setelah itu jawablah pertanyaan di bawah:

Tuliskan secara lengkap tahapan kalian dalam membuat lajengan (layang-layang) disertai alasan!

Dari pemberian tugas yang mengacu pada masalah kontekstual seperti diatas, siswa dimungkinkan mengetahui ukuran diagonal layang-layang, letak dan banyaknya sudut tumpul dan sudut lancip dan bagaimana sisi-sisinya. Dimungkinkan juga akan ada jawaban yang berbeda-beda dari setiap kelompok. Disini siswa membangun pengetahuan tentang sifat layang-layang.

b. Dari lajengan (bentuk layang-layang) yang kalian buat (poin a), amati kemudian buat simpulan tentang panjang dan banyaknya diagonal, panjang dan banyak sisi, serta banyak dan jenis sudut.

Masalah kontekstual diatas dimaksudkan untuk memantapkan pengetahuan siswa tentang sifat-sifat layang-layang. Dari simpulan yang dibuat, siswa diharapkan mengetahui kaitan antar diagonal, kaitan antar sisi, dan kaitan antar sudut.

c. Lihatlah gambar lajengan kreasi berikut. Tentukan banyaknya simetri lipat dan simetri putar yang dimiliki lajengan kreasi tersebut.

Gambar 7. Lajengan (Layangan)
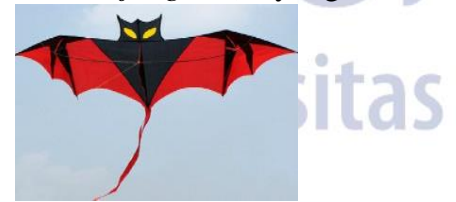

Sumber: https://www.google.co.id

Masalah diatas merupakan aplikasi dari penggunaan simetri lipat dan simetri putar pada bangun datar.

\section{Permainan Dhákoh (Dakon)}

Permainan dhẩkoh tersebar di seluruh Indonesia dengan nama yang berbeda-beda. Di jawa terkenal dengan nama dakon/congklak, Sumatra dengan nama congklak, dan di Sulawesi dengan nama mokaotan, maggaleceng, aggalacang dan nogarata. Permainan ini menggunakan alat yang terbuat dari kayu atau plastik dengan dua deret berisi lubang kecil berdiameter kurang lebih $5 \mathrm{~cm}$. Masing-masing deret ada sebanyak 7 lubang. Di bagian kanan dan kiri ada lubang berdiameter lebih besar kurang lebih $10 \mathrm{~cm}$ yang dinamakan roma (rumah/induk). Cara bermainnya dengan mengambil biji dhảkkoh dari salah satu lubang milik kita kemudian membagikannya pada lubang yang lain kecuali roma milik lawan begitu seterusnya hingga berhenti di lubang yang kosong.

Aturan permainan $d h \hat{a} k$ koh ini antara lain (1) dimainkan oleh dua orang, yang mendapat giliran bermain pertama kali biasanya ditentukan dengan suit, sedangkan untuk permainan berikutnya ditentukan dari pemain yang masih bisa bermain menjalankan biji dhåkkoh ketika mendapatkan giliran , (2) saat biji terakhir ada di lubang kosong milik sendiri maka bisa meddhil (mengambil biji milik lawan yang berada simetris dengan biji terakhir) dan saat biji terakhir ada di lubang kosong milik lawan maka bisa pekul (mengambil biji milik lawan yang berada di kanan dan kiri lubang tempat biji terakhir) (3) roma dhâkkoh milik lawan tidak ikut diisi dan jika biji terakhir ada di roma dhákkh maka berganti pemain, dan (4) pemenang ditentukan oleh pemain yang mendapatkan biji dhấkoh paling banyak.

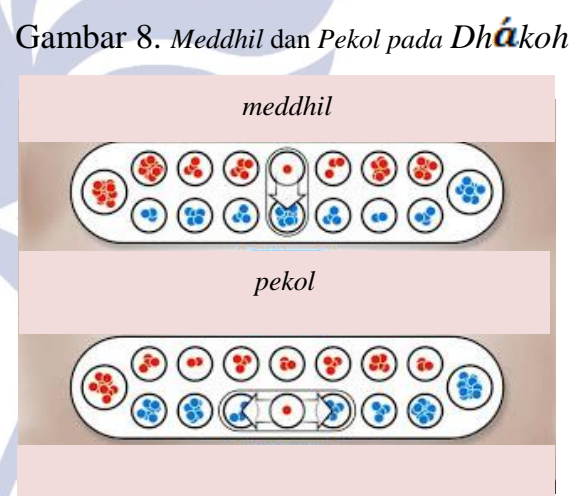

Aktivitas matematika yang dapat dilakukan dalam permainan ini adalah counting (membilang) dan playing (bermain). Prinsip matematika yang ada dalam permainan ini yaitu konsep pembagian, perkalian, penjumlahan, pengurangan, berhitung dan pengaturan strategi dan kecermatan untuk bisa menang dalam permainan. Anak yang bermain dhákkh akan membagi dengan adil biji dhấkoh ke setiap lubang dhấkoh. Selain itu pemain juga akan menghitung biji $d h$ á koh untuk mengetahui pemenangnya. Untuk bisa memenangkan permainan ini, anak harus memikirkan biji di lubang mana yang akan dimainkan hingga dia bisa memperoleh biji yang banyak.

Sesuai dengan Standar Isi 2006, permainan ini bisa dibawa dalam pembelajaran dengan mentransformasi 
prinsip matematika yang ada menjadi masalah kontekstual pada semua jenjang di sekolah dasar.

Contoh masalah matematika yang kontekstual dari permainan dhåkkoh sebagai berikut.

a. Ketika bermain dhákkoh, saya mendapatkan biji dhákkoh sebanyak 16. Berapa banyak lubang yang terisi penuh jika setiap lubang harus terisi 5 biji dhåkkoh?

b. Ani mendapatkan 46 biji dhấkoh dari permainan dh á koh yang dimainkannya bersama Ana. Berapakah biji dhákkoh Ana jika kesepakatan awal tiap lubang berisi 5 biji?

c. Dewi mempunyai biji dhák koh sebanyak 96. Berapakah isi dari masing-masing lubang dhåkkoh?

d. Dalam permainan dh á koh, Selma dan Siti mempunyai biji dhåkkoh sebanyak 96 biji. Tetapi mereka sepakat bahwa tiap lubang hanya diisi 4 biji. Berapakah biji dhâkkoh yang tidak terpakai?

e. Selma dan Siti bermain dhấkoh, di akhir permainan Selma mendapatkan biji lebih banyak daripada Siti hingga Selma bisa mengisi semua lubang dhấkohnya sesuai kesepakatan awal permainan yaitu 6 biji. Sebaliknya Siti hanya bisa mengisi penuh 4 lubang dhákkoh dan lubang lainnya terisi 4 biji sementara sisa lubang yang lain kosong. Berapakah KPK dan FPB dari jumlah biji dhákoh pada lubang milik Siti yang tidak terisi penuh dan jumlah biji dhâkoh salah satu lubang milik Selma?

f. Jika lubang dhấkoh pada deret lawan masingmasing terisi 4 biji dhåkoh, maka berapakah banyak biji dhåk koh seluruhnya yang digunakan untuk permainan?

g. Biji dhấkoh dari lubang manakah yang harus dijalankan, jika Ana mendapatkan giliran bermain agar bisa memperoleh biji dhákkoh dari Ani?

Gambar 9. Dhåk koh

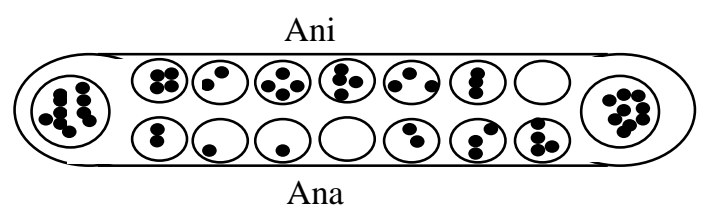

Contoh dari (a) hingga (f) merupakan contoh masalah kontekstual yang menggunakan aktivitas matematika counting (membilang) dengan menggunakan prinsip matematika pembagian, perkalian, penjumlahan, pengurangan dan berhitung. Sedangkan (g) merupakan contoh masalah kontekstual yang menggunakan aktivitas matematika playing (bermain) dengan prinsip matematika pengaturan strategi dan kecermatan untuk bisa menang dalam permainan. Dalam pembelajaran, contoh diatas merupakan aplikasi dari penggunaan operasi-operasi dalam matematika dan kecermatan dalam mengatur strategi.

\section{PENUTUP \\ Simpulan}

Demikian uraian tentang transformasi prinsip matematika pada permainan tradisional anak Madura menjadi masalah kontekstual dalam pembelajaran matematika di SD. Dari uraian diatas dapat ditarik beberapa simpulan sebagai berikut.

Permainan tradisional anak banyak mengandung ide-ide matematika yang bisa dimanfaatkan dalam pembelajaran, diantaranya permainan tanjen seribu, lajengan dan dhákoh. Dalam permainan tradisional, anak melakukan aktivitas-aktivitas matematika seperti counting dan playing pada permainan dhákkoh, locating, designing dan playing pada permainan lajengan, dan measuring dan playing pada permainan tanjen seribu.

Prinsip matematika dikembangkan dari aktivitas matematika pada setiap permainan. Dari prinsip-prinsip tersebut dibuat masalah-masalah yang kontekstual.

\section{Saran}

Bagi praktisi pendidikan khususnya tingkat sekolah dasar, dapat membuat masalah matematika yang kontekstual dengan mengambil ide-ide matematika dari keadaan sekeliling baik itu permainan ataupun tradisi-tradisi yang berkembang di lingkungan siswa.

\section{Daftar Pustaka}

Barton, W. D. 1996. Ethnomathematics: Exploring Cultural Diversity in Mathematics. A Thesis for Doctor of Philosophy in Mathematics Education University of Aucland: Unpublish.

Bishop, A. J. 1997. Educating the Mathematical Enculturator (Paper presented at ICMI China Regional Conference, Shanghai, China, August 1994). Papua New Guinea Journal of Teacher Education, 4(2), 17-20.

BSNP. 2006. Standar Isi untuk Pendidikan Dasar dan Menengah. Jakarta: -

D'Ambrosio, Ubiratan. 1985. Ethnomathematis and Its Place in the History and Pedagogy of Mathematics. For the Learning of Mathematics 5, 1 (February 1985). FLM Publishing Association, Montreal, Qucbec, Canada. 
Hanik, Umi. 2017. Etnomatematika Permainan Tradisional Anak Madura. Bangkalan: Penelitian tidak dipublikasikan

Nelissen, J. M. C. Tanpa tahun. Thinking Skill in RealisticMathematics.

http://www.fisme.science.uu.nl/publicaties/lit eratuur/6259.pdf (diunduh pada 14 Agustus 2017)

Soedjadi. 2007. Inti Dasar-Dasar Pendidikan Matematika Realistik Indonesia. Jurnal Pendidikan Matematika, Vol 1, No. 2.

Surahmi, Ema. 2016. Permainan Tradisional dalam Pembelajaran Matematika SD sebagai Bentuk Interaksi Sosial Siswa. Prosiding Semnasdik Prodi Pendidikan Matematika FKIP Universitas Madura, 132-139

Zulkardi dan Ratu Ilma. 2006. Mendesain Sendiri Soal Kontekstual Matematika. Paper terseleksi dan dipublikasikan pada prosiding KNM13 Semarang

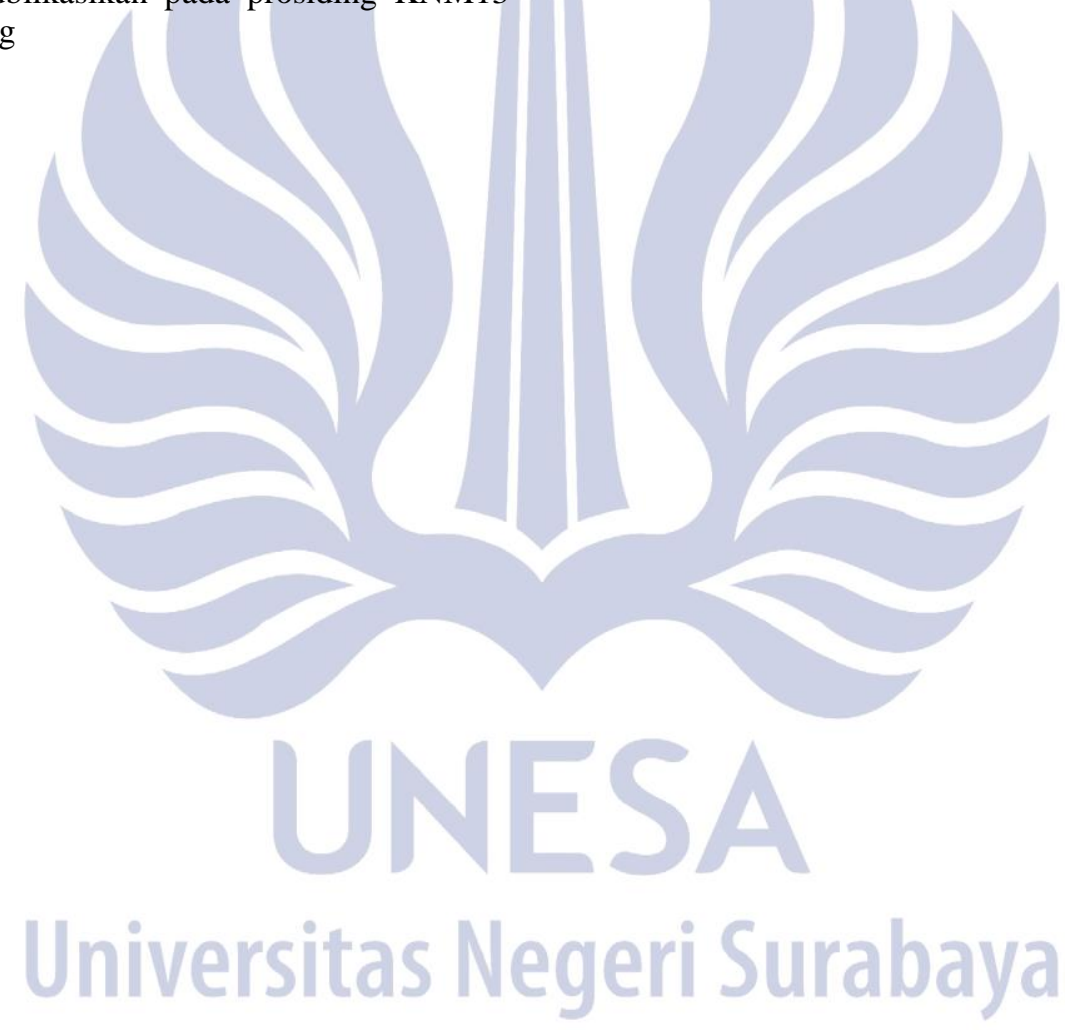

